\title{
Türkiye'de Kuru Fasulye Piyasasının Ekonomik Analizi ve Pazarlama Marjları
}

\author{
Uğur Küzeci $^{1^{*}} \quad$ Vedat Dağdemir $^{2} \quad$ Okan Demir $^{2}$ \\ ${ }^{1}$ Erzincan Binali Yıldırım Üniversitesi Meslek Yüksekokulu - Erzincan \\ ${ }^{2}$ Atatürk Üniversitesi Ziraat Fakültesi Tarım Ekonomisi Bölümü - Erzurum \\ ${ }^{1}$ Sorumlu yazar: ukuzeci@mynet.com
}

Geliş Tarihi: 28.03.2019

Kabul Tarihi: 23.09.2019

\section{$\ddot{\mathbf{O z}}$}

Bu çalışmada Türkiye'de kuru fasulyenin üretici-tüketici fiyatları ve pazarlama yapısı incelenmiștir. 2003-2017 yılları arasında üretim-tüketim, dış ticaret, fiyat dalgalanmaları ve pazarlaması üzerinde durulmuştur. Kuru fasulyenin cari ve reel fiyatlara göre pazarlama marjları hesap edilmiş. Cari fiyatlara göre üretici ve tüketici zincirleme indeksleri hesaplanarak yıllık enflasyon oranları ile karşılaştırılmıştır. Türkiye' de ekim alanları ve üretim miktarında düşüş, verimde ise artış olduğu tespit edilmiştir. Kuru fasulye üretim fonksiyonu ile ilgili model tahmin edilmiş, kuru fasulye üretimi üzerine tarım işçi reel fiyatı, mazot reel fiyatı ve trendin (zamanın) etkili olduğu bulunmuştur.

Anahtar Kelimeler: Kuru fasulye, pazarlama yapısı, fiyat dalgalanmaları

\section{Economic Analysis and Marketing Margins of Dry Bean Market in Turkey} Abstract

In this study, the producer-consumer prices and marketing structure of the dry beans in Turkey were examined. Between the years 2003-2017 the production-consumption, foreign trade, emphasized on price fluctuations and marketing. According to the current and real prices of dry beans marketing margins were calculated. According to current prices, producer and consumer chain indexes are calculated and compared with annual inflation rates. The reduction in the amount of acreage and production in Turkey, yield was determined as the increase. The model related to dry beans production function was estimated and it was found that agricultural real worker price, the diesel real price and the trend (time) was effective on dry beans production.

Keywords: Dry beans, marketing structure, price fluctuations

\section{Giriş}

Dünya üzerinde MÖ 5000 y1lından beri tarımı yapılan yemeklik tane baklagiller insan diyetlerinin önemli bir kısmını oluşturmuşlardır. Kuru fasulye, nohut, mercimek, bakla, bezelye ve börülceyi içine alan yemeklik tane baklagiller; diğer bitkisel ürünlere nazaran yüksek protein, düşük yağ, daha yüksek oranda vitamin ve mineral içermektedir (Şehirali 1988). Dünyada insan beslenmesindeki bitkisel proteinlerin \%22'sinin, karbonhidratların \%7'sinin, hayvan beslenmesindeki proteinlerin \%38'inin ve karbonhidratların \%5'inin yemeklik baklagillerden sağlandığ belirtilmektedir (Adak vd. 2010). Kuru fasulye ucuz protein kaynağ 1 olmasından dolayı özellikle gelişmekte olan ülkelerde nüfusun beslenme gereksinimlerinin karşılanması, kırsal nüfusun geçiminin sağlanması, özellikle Latin Amerika ülkelerinin geleneksel mutfak kültürlerinde yer alması ve uluslararası ticarete konu olması nedeniyle birçok ülkede üretilmektedir (Bolat, 2016).

Fasulye dünyada insan tüketiminde kullanılan en önemli baklagiller bitkisidir. Tarımı dünya üzerinde 1lıman bölgelerde yaygındır ve \%70 gibi yüksek bir oranla Asya ve Güney Amerika kıtalarında, daha çok gelişmekte olan ülkelerde yapılmaktadır (Özbekmez, 2015). Kuru fasulye dünya genelinde 300 milyondan fazla insanın günlük beslenmesinde yer alan önemli bir besin kaynağıdır. Bünyesindeki protein, diyetsel lif ve mineral maddeler nedeniyle "süper besin" olarak bilinmektedir (Saleh ve ark., 2012).

Fasulye, sebze, taze tane, konserve ve kuru tane gibi değişik şekillerde değerlendirilen ve ülkemizde sevilerek tüketilen bir bitkidir. Tazesi mineraller ve vitaminlerce, kuru tanesi ise proteince zengin bir üründür (Balkaya, 1999). 
Fasulye ülkemizde çok sevilen ve tüketilen önemli bir yemeklik tane baklagiller bitkisidir. Ancak üretim sorunlarının belirlenmesi ve çözümüne yönelik çabaların yetersizliği, ıslah edilmiş yeterince çeşidin olmayışı ya da ekilişlerinin yaygınlaştırılamaması fasulye üretimindeki atılımları kısıtlamıştır. Ülke genelinde fasulyenin en fazla yetiştiği bölgelerden biri Karadeniz Bölgesi olmasına rağmen, bölgede verim Türkiye ortalamasının çok altındadır (Bozoğlu ve Gülümser, 1998).

Türkiye'de nüfusun \%10,0'ında beslenmede protein yetersizliği, $\% 22,5$ 'inde ise protein yönünden dengesiz beslenme olduğu dikkate alınırsa kuru fasulyenin, genel anlamda da yemeklik tane baklagillerin önemi ortaya çıkacaktır. Son y1llarda ülkemizde tüketilen y1llık toplam baklagiller miktarı yaklaşık 1,0-1,2 milyon ton ve kişi başına yıllık tüketimi ise $15 \mathrm{~kg}$ civarında olmuştur (Sepetoğlu, 2006).

Türkiye'de ekiliş alanı bakımından baklagiller, tahıllardan sonra en önemli yeri tutmaktadır. Üretimi yapılan 9 çeşit baklagillerden en fazla yetiştirilenleri ise nohut, kuru fasulye ve mercimektir. 2017 yılı itibariyle, baklagiller yaklaşık 7,9 milyon dekar alanda ekili olup toplam ekili alanın \%2'sini oluşturmuş ve 1,2 milyon ton baklagiller üretimi gerçekleştirilmiştir. Kuru fasulye toplam baklagiller ekim alanının \%11,3'ünü, toplam baklagiller üretim miktarının ise \%20'sini oluşturmaktadır (TÜİK, 2019). Dünya genelinde üretilen bakliyatın yaklaş1k \%84'ü ülkelerin iç talebini karşılamaya yöneliktir. Geriye kalan \%16'lık kısım ise dünya ticaretine dâhil olmaktadır (Anonim, 2017). Dünya kuru fasulye ekimi 2016 yılında 29,393 milyon hektar alanda gerçekleşmiş olup bu ekim alanlarının, \%52,4'ü Hindistan (15 425864 ha), \%10,8'ini Myanmar (3 182144 ha), \%9,5'ini ise Brezilya (2 795284 ha) oluşturmuştur. Türkiye ise ekim alanı itibarıyla \% 0,31 (89 820 ha) pay ile 39 . sırada yer almaktadır (FAO, 2019).

Dünya kuru fasulye üretimi 2016 yılında 26833 milyon ton olarak gerçekleşmiştir. Üretimde birinci sıray1 6,39 milyon ton ile Hindistan alırken bunu sirasiyla 5,46 milyon ton ile Myanmar ve 3,033 milyon ton ile Brezilya takip etmektedir. Türkiye 239 bin ton üretim ile 23. sirada yer almaktadır (FAO, 2019). Dünya kuru fasulye ihracatı 2016 y1lında 2,6 milyon ton olarak gerçekleşmiştir. Kuru fasulye ihracatında \%22,7'lik pay (590 564 ton) ile ilk sırayı Çin, ABD \%18,2'lik pay (473 975 ton) ile ikinci ve Arjantin \%16,7'lik pay (436 055 ton) ile üçüncü sırada yer almaktadır. Myanmar ve Hindistan dünyada önemli kuru fasulye üreticileri olmalarına rağmen iç tüketimlerinin fazla olması nedeniyle ihracattan önemli ölçüde pay alamamaktadır. Çin ise daha çok ihracat amacı ile üretim yapmaktadır. Türkiye 2700 ton ihracat ile 47. sırada yer almaktadır (FAO, 2019). Kuru fasulye ithalatında \%29,0'lık pay (727 583 ton) ile ilk sırayı Hindistan, Brezilya \%14'lük pay (350 000 ton) ile ikinci ve ABD \%7,0'l1k pay (172 681 ton) ile üçüncü sırada yer almaktadır. Türkiye 33894 ton ile ithalatta 17. sirada yer almaktadır (FAO, 2019).

Yemeklik tane baklagillerden olan kuru fasulyede son yıllarda ekiliş alanında ve ihracatta düşüş, ithalatta ise yükseliş gözlemlenmektedir. Bu durum Türkiye tarımı açısından önemli bir problem olarak ortaya çıkmaktadır. Kuru fasulye piyasasının incelenerek sonuçlara göre önerilerde bulunulması amaçlanmıştır. Bu çalışmada kuru fasulye üretici-tüketici fiyatları dikkate alınarak ekonomik analizler yapılarak pazarlama durumu incelenmiştir. Ayrıca kuru fasulye üretim fonksiyonu ile ilgili model tahmin edilerek kuru fasulye üretimi üzerine etkili olan faktörlerin etki dereceleri ölçülmeye çalışılmıştır.

\section{Materyal ve Metot \\ Materyal}

Bu çalışmada 2003-2017 yılları arasında kuru fasulyenin üretim miktarı, ekim alanları ve verim miktarları Türkiye İstatistik Kurumuna (TUIKK) ait, kuru fasulyenin üretici fiyatları (çiftçi eline geçen), perakende fiyatları (tüketici), ithalat-ihracat miktarları ise Türkiye İstatistik Kurumu (TUIK), Food and Agriculture Organization (FAO) Türkiye Odalar ve Borsalar Birliği (TOBB), Türkiye İhracatçılar Meclisi (TIM), Tarımsal Ekonomi ve Politika Geliştirme Enstitüsüne (TEPGE) ait web sitelerinden elde edilen veriler kullanılmıştır. Gübre fiyatı, mazot fiyatı, tarım işçi fiyatı TÜİK ve TEPGE'ye ait web sitesinden, yıllara göre yağış miktarı ise Meteoroloji genel müdürlüğünden alınmıştır. Ayrıca çeşitli yayın ve kaynaklardan da yararlanılmıştır.

Metot

Kuru fasulye üretici ve tüketici cari fiyatları, üretici ve tüketici fiyat indeksleri $(2017=100)$ dikkate alınarak reel fiyatlara dönüştürülmüştür. Fiyatlardaki yıldan yıla dalgalanmalar, önce mutlak 
değerler halinde gösterilmiş, daha sonra karşıllaştırılan iki yıldan, ilkinin yüzdesi halinde ifade edilmiştir. Elde edilen yüzde oranlarının işaretleri dikkate alınmadan ortalamalar hesaplanmıştır (Dağdemir ve Birinci, 1999; Altundağ ve Güneş, 1992). Çiftçi eline geçen fiyatlar (üretici fiyatları) ile tüketicinin ödediği fiyatlar arasındaki fark "Pazarlama Marjı" olarak hesaplanmıştır (Aşkan ve Dağdemir, 2015; Topcu, 2003; Topcu, 2004). Zincirleme fiyat indeksi hesap edilirken 2003-2017 y11 aralığı ele alınarak üretici ve tüketici cari fiyatları yıldan yıla karşılaştırmalı olarak hesap edilmiştir. Zincirleme fiyat indeksinde temel yıl yoktur. Herhangi bir y1la ait indeks, bir önceki y1lın fiyatı temel alınarak hesaplanmıştır. Zincirleme fiyat indeksinde asıl amaç, fiyatın zamanda yıllık değişmelerini incelemek, yani bir sonraki yılda bir önceki yıla göre fiyatların ne oranda arttığını ya da azaldığını belirlemektir (Dağdemir, 1998).

Kuru fasulye üretim fonksiyonuyla ilgili model tahmin edilirken, seriler tek tek doğrusal, çift logaritmik ve yarı logaritmik modellerde denenmiştir. Yapılan analizlerde en uygun istatistiki sonuçları veren çift logaritmik model (Log-Log) kullanılmıştır. Tüm bağımsız değişkenlerdeki fiyatlar reel olarak $(2017=100)$ dikkate alınmıştır. Kurulan modellerde zaman serisi analizlerinde görülen otokorelasyon probleminin olup olmadığını anlamak için Durbin-Watson testi uygulanmış ve otokorelasyon probleminin olmadığı anlaşılmıştır.

Kuru fasulye üretim fonksiyonu ile ilgili tahmin edilen model formül 1'deki gibidir.$$
\log F U_{(t)}: \alpha+\beta_{1} \log G F+\beta_{2} \log I F+\beta_{3} \log M F+\beta_{4} D+\beta_{5} \log T+\epsilon
$$$$
F U \text { : Kuru Fasulye Üretim Miktarl (ton) }
$$$$
\text { GF : Gübre Reel Fiyatı (Đ/ton) }
$$$$
\text { IF : Tarım İşçi Reel Fiyatı (Đ/ay) }
$$$$
\text { MF : Mazot Reel Fiyatı (Đ/lt) }
$$$$
\text { D : Dummy Değişkeni (2003-2017 yılları ortalama yağış miktarı 627,3 mm'dir. Yıllara göre }
$$ \\ ortalama altı"0", ortalama üstü "1" kabul edilmiştir. \\ $T$ : Trend(2003-3017 ylllarl; 1,2,3, ... 15).
}

\title{
Bulgular ve Tartışma
}

Türkiye'de 2003 yılında 1,62 milyon dekarda 250 bin ton üretimi gerçekleştirilen kuru fasulye, 2017 yılında ekim alanları \%55,0'lık düşüşle yaklaşık 900 bin dekara, üretim ise \%9,5'lik düşüşle 239 bin tona gerilemiştir. Üretim alanlarında ve üretimde gerilemenin aksine verim ortalamasında \%72,0'lık bir artış meydana gelerek $154 \mathrm{~kg} / \mathrm{da}$ 'dan $266 \mathrm{~kg} / \mathrm{da}$ 'a çıkmıştır. Ekim alanı ortalamas1 2003-2017 yılları arasında 1086561 dekar, üretim ortalamas1 208565 ton, verim ortalamas1 ise $199 \mathrm{~kg}$ /da olmuştur. Verimin en yüksek olduğu y1l $266 \mathrm{~kg} / \mathrm{da}$ ile 2017 y1lı olurken, verimin en düşük olduğu y1l $141 \mathrm{~kg} / \mathrm{da}$ ile 2007 y1lı olmuştur (Çizelge 1).

Kuru fasulyenin toplam tüketimi 2003 yllında 212620 ton iken \%30,0 artarak 2017 y1linda 276034 ton olarak gerçekleşmiştir. 2003 yılında kişi başına tüketim 3,16 kg/yıl iken 2017 yılında \%8 artarak kişi başına tüketim 3,42 kg/y1l olmuştur. Kuru fasulyenin kişi başına tüketim ortalaması ise $3,18 \mathrm{~kg} / \mathrm{yll}$ 'dır. Kuru fasulyenin tüketim ortalamasının en yüksek olduğu 3,58 kg/y1l ile 2004 yıl1, tüketim ortalamasının en düşük olduğu yıl ise 2,67 kg ile 2007 yılıdır. Türkiye'de y1llara göre kuru fasulye tüketim ortalamasının birbirine yakın olduğu görülmektedir. 2003-2017 yılları arasında üretimde düşüş $(\% 4,6)$, nüfustaki artış $(\% 20,0)$ olmasına rağmen, verim $(\% 72,7)$ ve ithalattaki $(\% 681,3)$ artıştan dolayı tüketim ortalaması birbirine yakın değerlerde muhafaza edilmiştir (Çizelge.2).

Kuru fasulyede 2003 yılında \%118,0 olan üretimdeki yeterlilik oranı 2017 yılında \%86,5 oranına düşmüştür. 2003-2017 yılları arası ihracat ortalamas1 9200 ton, ithalat ise 35077 tondur. İhracatta 2003-2017 yılarında \%691,0'lık düşüş, ithalatta ise \%681,3'lük bir artış gerçekleşmiştir. İthalatın en yüksek olduğu yıl 53737 ton ile 2009 yılı iken ithalatın en düşük olduğu y1l ise 6365 ton ile 2003 yılıdır. İhracatın en yüksek olduğu yıl 43745 ton ile 2003 y1lı iken ihracatın en düşük olduğu y1l ise 2399 ton ile 2011 y1lıdır (Çizelge.2). 
Çizelge 1. Türkiye'de kuru fasulye ekiliş, üretim ve verim durumu

\begin{tabular}{|cccc|}
\hline Yıllar & $\begin{array}{c}\text { Ekim Alani } \\
\text { (da) }\end{array}$ & $\begin{array}{c}\text { Miktar } \\
\text { (ton) }\end{array}$ & $\begin{array}{c}\text { Verim } \\
\text { (kg/da) }\end{array}$ \\
\hline 2003 & 1620000 & 250000 & 154 \\
2004 & 1550000 & 250000 & 161 \\
2005 & 1412000 & 210000 & 149 \\
2006 & 1290515 & 195970 & 152 \\
2007 & 1092497 & 154243 & 141 \\
2008 & 982326 & 154630 & 157 \\
2009 & 949280 & 181205 & 191 \\
2010 & 1033811 & 212758 & 206 \\
2011 & 946254 & 200673 & 212 \\
2012 & 931740 & 200000 & 215 \\
2013 & 847630 & 195000 & 230 \\
2014 & 911103 & 215000 & 236 \\
2015 & 935840 & 235000 & 251 \\
2016 & 898197 & 235000 & 262 \\
2017 & 897221 & 239000 & 266 \\
Ort. & $\mathbf{1 0 8 6 5 6 1}$ & $\mathbf{2 0 8 5 6 5}$ & $\mathbf{1 9 9}$ \\
\hline
\end{tabular}

Kaynak: tuik.gov.tr. 2018

Çizelge 2. Türkiye'de kuru fasulye üretim, tüketim ve pazarlaması

\begin{tabular}{|cccccr|}
\hline Yıllar & $\begin{array}{c}\text { Üretim } \\
\text { (ton) }\end{array}$ & $\begin{array}{c}\text { Tüketim } \\
\text { (ton) }\end{array}$ & $\begin{array}{c}\text { Kişi Başı } \\
\text { Tüketim } \\
\text { (kg/yıl) }\end{array}$ & $\begin{array}{c}\text { İthalat } \\
\text { (ton) }\end{array}$ & $\begin{array}{c}\text { İhracat } \\
\text { (ton) }\end{array}$ \\
\hline 2003 & 250000 & 212620 & 3,16 & 6365 & 43745 \\
2004 & 250000 & 243666 & 3,58 & 13964 & 20298 \\
2005 & 210000 & 244110 & 3,54 & 37730 & 3620 \\
2006 & 195970 & 222501 & 3,19 & 31000 & 4469 \\
2007 & 154243 & 188628 & 2,67 & 37527 & 3142 \\
2008 & 154630 & 202400 & 2,83 & 52482 & 4712 \\
2009 & 181205 & 214930 & 2,96 & 53737 & 20012 \\
2010 & 212758 & 248090 & 3,37 & 38064 & 2732 \\
2011 & 200673 & 233850 & 3,13 & 35576 & 2399 \\
2012 & 200000 & 227981 & 3,01 & 30390 & 2409 \\
2013 & 195000 & 217039 & 2,83 & 25599 & 3560 \\
2014 & 215000 & 257302 & 3,31 & 52836 & 10534 \\
2015 & 235000 & 262135 & 3,33 & 32919 & 5784 \\
2016 & 235000 & 265339 & 3,32 & 34605 & 4266 \\
2017 & 239000 & 276034 & 3,42 & 43364 & 6330 \\
Ort. & $\mathbf{2 0 8 5 6 5}$ & $\mathbf{2 3 4 4 4 2}$ & $\mathbf{3 , 1 8}$ & $\mathbf{3 5 0 7 7}$ & $\mathbf{9 2 0 0}$ \\
\hline
\end{tabular}

Kaynak: Orijinal hesaplamalar.

Cari fiyatlarda 2003 y1lında 1,52 €/kg olan kuru fasulyenin üretici fiyatları \%262 artarak 2017 y1lında 3,98 €/kg, 2003 yılında 2,02 €/ kg olan tüketici fiyatları ise \%569 artarak 2017 y1lında 11,5 € $/ \mathrm{kg}$ olmuştur. Kuru fasulyenin üretici fiyatlarında en fazla artış 2008 yılında gerçekleşmiş ve bir önceki yıla göre $\% 23$ artış ile 2,12 €/kg'dan 2,63 € $/ \mathrm{kg}$ 'ye çıkmıştır. Tüketici fiyatındaki en yüksek artış ise 2014 yılında \%50,7'lik oranında artış göstermiş ve fiyatlar 6,35 £/kg'dan 9,57 £/kg'a çıkmıştır (Çizelge 3). 
Tüketicinin bir kg kuru fasulyeye ödediği fiyat ile bir kg kuru fasulyeye karşılık çiftçi eline geçen fiyat arasındaki fark pazarlama marjını vermektedir. Yani, pazarlama marjı ile aracıların eline geçen değer kastedilmektedir. Cari fiyatlar dikkate alındığında, yıllara göre aracıların eline geçen oranlar \%21 - \%66, çiftçi eline geçen oranlar ise \%34 - \%79 arasında değişmektedir (Çizelge 3).

Çizelge 3. Türkiye'de cari fiyatlara göre kuru fasulyenin pazarlama marjları

\begin{tabular}{|c|c|c|c|c|c|}
\hline Yillar & $\begin{array}{c}\text { Üretici } \\
\text { Fiyatları } \\
\text { (\$)/kg) }\end{array}$ & $\begin{array}{c}\text { Tüketici } \\
\text { Fiyatları } \\
\text { (I/kg) }\end{array}$ & $\begin{array}{c}\text { Pazarlama } \\
\text { Marjı }\end{array}$ & $\begin{array}{l}\text { Üretici Eline } \\
\text { Geçen(\%) }\end{array}$ & $\begin{array}{c}\text { Aracı Eline } \\
\text { Geçen }(\%)\end{array}$ \\
\hline 2003 & 1,52 & 2,02 & 0,50 & 75 & 25 \\
\hline 2004 & 1,66 & 2,10 & 0,44 & 79 & 21 \\
\hline 2005 & 1,67 & 2,87 & 1,20 & 58 & 42 \\
\hline 2006 & 1,87 & 3,06 & 1,19 & 61 & 39 \\
\hline 2007 & 2,12 & 3,35 & 1,23 & 63 & 37 \\
\hline 2008 & 2,61 & 4,63 & 2,02 & 56 & 44 \\
\hline 2009 & 2,48 & 4,48 & 2,00 & 55 & 45 \\
\hline 2010 & 2,39 & 4,28 & 1,89 & 56 & 44 \\
\hline 2011 & 2,50 & 4,29 & 1,79 & 58 & 42 \\
\hline 2012 & 2,91 & 5,08 & 2,17 & 57 & 43 \\
\hline 2013 & 3,28 & 6,35 & 3,07 & 52 & 48 \\
\hline 2014 & 3,68 & 9,57 & 5,89 & 39 & 61 \\
\hline 2015 & 3,39 & 7,97 & 4,58 & 42 & 58 \\
\hline 2016 & 3,44 & 10,00 & 6,56 & 34 & 66 \\
\hline 2017 & 3,98 & 11,50 & 7,52 & 35 & 65 \\
\hline
\end{tabular}

Kaynak: Orijinal hesaplamalar.

Kuru fasulye reel fiyatları incelendiğinde 2003 yılında kuru fasulyenin üretici reel fiyatı 4,75 €/kg iken 2017 yılında 3,98 €/kg'dır. Tüketici reel fiyatları incelendiğinde ise 2003 y1lında 6,03 €/kg olan tüketici reel fiyatı 2017 yılında 11,5 €/kg olarak belirlenmiştir. Tüketicilerin kuru fasulye satın alma paritesi \%91 oranında azalmıştır. Üreticinin $1 \mathrm{~kg}$ kuru fasulye üretimden elde ettiği kazanç on beş yılda \%16,2 oranında artmıştır. Tüketicinin $1 \mathrm{~kg}$ kuru fasulye tüketim için ödediği rakam \%90,7 oranında artmıştır. On beş yıllık süreçte reel olarak üreticilerin lehine, tüketicinin ise aleyhine bir durum olmuştur. Reel fiyatlar dikkate alındığında, yıllara göre aracıların eline geçen oranlar \%16 $\% 67$, çiftçi eline geçen oranlar ise \%33 - \%84 arasında değişmektedir (Çizelge 4).

Çizelge 5'de kuru fasulye cari fiyatlarına göre üretici ve tüketici zincirleme indeksleri hesaplanmış ve bunların yıllara göre farkları alınarak enflasyon oranları ile karşılaştırılmıştır. $\mathrm{Bu}$ karş1laştırma sonucunda, kuru fasulyede üretici eline geçen fiyatların 2006, 2007, 2008, 2012, 2013, 2014 ve 2017 yıllarında enflasyon oranının üstünde olduğu tespit edilmiştir. Tüketicinin durumunu incelendiğimiz zaman 2004, 2006, 2009, 2010, 2011 ve 2015 yıllarında tüketicinin satın alma gücü artarken diğer yıllarda ise satın alma gücü düşmüştür. 
Çizelge 4.Türkiye'de reel fiyatlara göre kuru fasulyenin pazarlama marjları

\begin{tabular}{|c|c|c|c|c|c|}
\hline Yillar & $\begin{array}{c}\text { Üretici } \\
\text { Fiyatları } \\
\text { (İ/kg) }\end{array}$ & $\begin{array}{c}\text { Tüketici } \\
\text { Fiyatları } \\
\text { (f/kg) }\end{array}$ & $\begin{array}{c}\text { Pazarlama } \\
\text { Marjı }\end{array}$ & $\begin{array}{c}\text { Üretici Eline } \\
\text { Geçen(\%) }\end{array}$ & $\begin{array}{c}\text { Aracı Eline } \\
\operatorname{Geçen}(\%)\end{array}$ \\
\hline 2003 & 4,75 & 6,03 & 1,28 & 79 & 21 \\
\hline 2004 & 4,76 & 5,67 & 0,91 & 84 & 16 \\
\hline 2005 & 4,42 & 7,16 & 2,74 & 62 & 38 \\
\hline 2006 & 4,54 & 6,95 & 2,41 & 65 & 35 \\
\hline 2007 & 4,72 & 7,16 & 2,44 & 66 & 34 \\
\hline 2008 & 5,27 & 8,78 & 3,51 & 60 & 40 \\
\hline 2009 & 4,71 & 8,39 & 3,68 & 56 & 44 \\
\hline 2010 & 4,18 & 7,39 & 3,21 & 57 & 43 \\
\hline 2011 & 4,11 & 6,67 & 2,56 & 62 & 38 \\
\hline 2012 & 4,39 & 7,44 & 3,06 & 59 & 41 \\
\hline 2013 & 4,60 & 8,90 & 4,30 & 52 & 48 \\
\hline 2014 & 4,75 & 12,17 & 7,42 & 39 & 61 \\
\hline 2015 & 4,06 & 9,63 & 5,57 & 42 & 58 \\
\hline 2016 & 3,83 & 11,58 & 7,75 & 33 & 67 \\
\hline 2017 & 3,98 & 11,50 & 7,52 & 35 & 65 \\
\hline
\end{tabular}

Kaynak: Orijinal hesaplamalar.

Çizelge 5.Türkiye'de cari fiyatlarına göre kuru fasulye üretici-tüketici zincirleme indeksleri ve yıllık enflasyon oranları

\begin{tabular}{lrrrrrr}
\hline Yıllar & $\begin{array}{c}\text { Üretici } \\
\text { Zincirleme } \\
\text { İndeksi }\end{array}$ & $\begin{array}{c}\text { Üretici } \\
\text { İndeks } \\
\text { Farkı }\end{array}$ & ÜFE & $\begin{array}{c}\text { Tüketici } \\
\text { Zincirleme } \\
\text { İndeksi }\end{array}$ & $\begin{array}{c}\text { Tüketici } \\
\text { İndeks Farkı }\end{array}$ & TÜFE \\
\cline { 2 - 7 } $\mathbf{2 0 0 3}$ & 100,0 & - & 13,9 & 100,0 & - & 18,4 \\
$\mathbf{2 0 0 4}$ & 109,2 & 9,2 & 13,8 & 104,0 & 4,0 & 9,3 \\
$\mathbf{2 0 0 5}$ & 100,6 & 0,6 & 2,7 & 136,7 & 36,7 & 7,7 \\
$\mathbf{2 0 0 6}$ & 112,0 & 12,0 & 11,6 & 106,6 & 6,6 & 9,7 \\
$\mathbf{2 0 0 7}$ & 113,4 & 13,4 & 5,9 & 109,5 & 9,5 & 8,4 \\
$\mathbf{2 0 0 8}$ & 123,1 & 23,1 & 8,8 & 138,2 & 38,2 & 10,1 \\
$\mathbf{2 0 0 9}$ & 95,0 & $-5,0$ & 5,9 & 96,8 & $-3,2$ & 6,5 \\
$\mathbf{2 0 1 0}$ & 96,4 & $-3,6$ & 8,9 & 95,5 & $-4,5$ & 6,4 \\
$\mathbf{2 0 1 1}$ & 104,6 & 4,6 & 13,3 & 100,2 & 0,2 & 10,5 \\
$\mathbf{2 0 1 2}$ & 116,4 & 16,4 & 2,5 & 118,4 & 18,4 & 6,2 \\
$\mathbf{2 0 1 3}$ & 112,7 & 12,7 & 7,0 & 125,0 & 25,0 & 7,4 \\
$\mathbf{2 0 1 4}$ & 112,2 & 12,2 & 6,4 & 150,7 & 50,7 & 8,2 \\
$\mathbf{2 0 1 5}$ & 92,1 & $-7,9$ & 5,7 & 83,3 & $-16,7$ & 8,8 \\
$\mathbf{2 0 1 6}$ & 101,5 & 1,5 & 9,9 & 125,5 & 25,5 & 8,5 \\
$\mathbf{2 0 1 7}$ & 115,7 & 15,7 & 15,5 & 115,0 & 15,0 & 11,9 \\
\hline
\end{tabular}

Kaynak: Orijinal Hesaplamalar.

Çizelge 6. Kuru fasulye üretim fonksiyonuyla ilgili regresyon analizi sonuçları

\begin{tabular}{r|rlccc}
\hline LogFU & Katsayllar & Standart Hata & P (t) & P (F) \\
\hline$\alpha$ & 22,2028 & $* * *$ & 3,5064 & 0,000 & \\
$\log \mathrm{GF}$ & 0,2550 & 0,2426 & 0,321 & \\
$\operatorname{LogIF}$ & $-1,2265$ & $* *$ & 0,4966 & 0,036 & 0,062 \\
$\operatorname{LogMF}$ & $-1,0911$ & $* * *$ & 0,3338 & 0,001 & \\
$\mathrm{D}$ & $-0,0120$ & & 0,0714 & 0,870 & \\
LogT & 0,3347 & $* *$ & 0,1431 & 0,044 & \\
\hline
\end{tabular}

$*: \% 10, * *: \% 5$ ve ***:\%1 önem seviyelerinde anlamlıdır. 
Kuru fasulyenin üretim fonksiyonunu ile ilgili olarak tahmin edilen modelde tespit edilen işaretlere göre, kuru fasulyenin üretimi ile tarım işçi reel fiyatı, mazot reel fiyatı ve yağış miktarı (dummy) arasında ters bir ilişki, gübre reel fiyatı ve trend (zaman) arasında ise doğru bir ilişkinin bulunduğu görülmektedir. Kuru fasulyenin üretimi ile gübre reel fiyatı arasında doğru bir ilişkinin, yağış miktarıyla (dummy) ise ters bir ilişkinin olduğu görülmekte olup ekonomik teoriye uymayan bir durumdur. Zaman serisi verilerinin kullanılması sonucu katsayıların işaretlerinde ekonomik teoriye ters sonuçlar da çıkabilmektedir.

Modelde $\mathrm{R}^{2}$ değeri yüksek $(0,640)$ olup yapılan $\mathrm{F}$ testine göre kuru fasulyenin üretim fonksiyonu için tahmin edilen model \%10 ( $\mathrm{P}=0,062)$ önem seviyesinde istatistiki olarak anlamlı bulunmuştur. Yine bağımsız değişkenlerden tarım işçi reel fiyatı ve trend $\% 5$, mazot reel fiyatı $\% 1$ önem seviyesinde istatistiki olarak önemli, diğer bağımsız değişkenlerin önemsiz olduğu tespit edilmiştir. Modelde tahmin edilen anlamlı katsayılara göre tarım iş̧̧ilik maliyetlerini \%1 arttırdığımızda kuru fasulye üretiminde $\% 1,2265$ 'lik, mazot reel fiyatlarını $\% 1$ arttırdığımızda kuru fasulye üretiminde \%1,0911'lik bir azalışın meydana geleceği öngörülmektedir. Trend (zaman) ile kuru fasulye arasında doğru yönlü bir ilişki vardır. Yani zaman içinde teknolojik gelişmelerin kuru fasulye üretimini olumlu etkilediği varsayılabilmektedir. Buna göre teknolojik gelişmeler \%1 arttı̆̆ zaman kuru fasulye üretiminde \%0,3347'lik artışın olacağ 1 varsayılmaktadır.

\section{Sonuç ve Öneriler}

Cari ve reel olarak yapılan hesaplamalarda son yıllarda pazarlama marjı hesabında aracilar eline geçen oranın yükseldiği gözlemlenmiştir. Yine ithalatta yıllara göre artış, ihracatta ise azılış olmuştur. Verim yükselmesine rağmen ekiliş alanlarında önemli düşüş yaşanmıştır. İthalata dayalı bir sisteme doğru gidilmekte, aracıların etkisi artmakta, çiftçi eline geçen oran azalmaktadır. Ekiliş alanlarının artırılması için çiftçinin bu konuda desteklenmesi gerekmektedir. Özellikle üretim modelinde yapılan analize göre de önemli girdilerin sübvanse edilmesi ile maliyetler düşürülebilir. $\mathrm{Bu}$ durumda üretim artacak, ithalat azalacak, çiftçi eline geçen oran da artabilecektir.

\section{Kaynaklar}

Adak, M.S., Güler, M. Kayan, N., 2010. Yemeklik baklagillerin üretimini artırma olanakları. VII. Türkiye Ziraat Mühendisliği Teknik Kongresi, ZMO Yayınları, ANKARA.

Altundağ, S., Güneş, T., 1992. Türkiye'de patates ve soğanın üretim miktarı ile fiyat $\quad$ ilişkileri. Ankara Üniversitesi Ziraat Fakültesi Yıllığı. Ankara Üniversitesi Basımevi, Ankara. s.52-65.

Anonim, 2017. http://www.millermagazine.com/dunya-kuru-fasulyenohut-pazarı/.html

Aşkan, E., Dağdemir, V., 2015. Türkiye sarımsak piyasasının ekonomik analizi. Alınteri Zirai Bilimler Dergisi, 28(B), 19-26. ISSN: 1307-3311.

Balkaya, A., 1999. Karadeniz bölgesindeki taze fasulye (Phaseolus vulgaris L.) gen kaynaklarının toplanması, fenolojik ve morfolojik özelliklerinin belirlenmesi ve taze tüketime uygun tiplerin teksel seleksiyon yöntemi ile seçimi üzerinde araştırmalar. Ondokuz Mayıs Üniversitesi Fen Bilimleri Enstitüsü Bahçe Bitkileri Ana Bilim Dalı, Samsun. Doktora Tezi.

Bolat, M., 2018. Kuru fasulye ürün raporu. Tepge Yayın No301, ISBN 978-605-2207-09-03.

Bozoğlu, H., Gülümser, A., 1998. Kuru fasulyede bazı tarımsal özelliklerin genotip çevre interaksiyonları ve stabilitelerinin belirlenmesi. Tr. J.Agric. and Forestry, (24): 211-220.

Dağdemir, V., 1998. Türkiye soğan piyasasının ekonomik analizi. Atatürk Üniversitesi İktisadi ve İdari Bilimler Dergisi, 12(1/2): 99-114

Dağdemir, V., Birinci, A., 1999. Türkiye'de patates pazarlaması ve fiyat dalgalanmalarının üretim üzerine etkisi. II. Ulusal Patates Kongresi, 28 - 30 Haziran, Erzurum.

FAO, 2019. http://www.fao.org,

Özbekmez, Y., 2015. Ordu ekolojik koşullarında bazı kuru fasulye çeşit ve genotiplerinin verim ve verim öğeleri ile tohum ve teknolojik özelliklerinin belirlenmesi. Ordu Üni. Fen Bilimleri Enstitüsü, Tarla Bitkileri ABD, Yüksek Lisans tezi.

Saleh, S.M., Abou-Shleel, S.M., Abou-Hadid, A.F., 2012. Prediction and adaptation of dry bean yield under climate change conditions. Research Journal of Agriculture and Biological Sciences, 8(2): 147-153.

Sepetoğlu, H., 2006. Tarla Bitkileri I, Ege Üniversitesi Ziraat Fakültesi Yayınları No: 569, İzmir.

Şehirali, S., 1988. Yemeklik Dane Baklagiller Kitabı, Ankara Üniversitesi Ziraat Fakültesi Yayınları Ders Kitabi:314, Ankara. 
ÇOMÜ Zir. Fak. Derg. (COMU J. Agric. Fac.)

2019: 7 (2): 379-386

ISSN: 2147-8384 / e-ISSN: 2564-6826

doi: 10.33202/comuagri.545838

TEPPGE, 2019. https://arastirma.tarimorman.gov.tr/tepge

TIM, 2019. http://www.tim.org.tr/

TOBB, 2019. https://www.tobb.org.tr

Topcu, Y., 2003. Gıda ürünlerinde pazarlama marjı ve cebirsel analiz. Atatürk Üniv. Zir. Fak. Dergisi, 34(2): 199-207.

Topcu, Y., 2004. A Study on the Meat Cost and Marketing Margins of Cattle Fattening Farms in Erzurum Province. Turkish Journal of Veterinary and Animal Sciences, 28(6): 1007-1015.

TUIK, 2019. http://www.tuik.gov.tr 